\title{
MANAJEMEN KESEHATAN PESERTA DIDIK SEKOLAH DASAR
}

\author{
Oleh : \\ Anna Susana \\ Yayasan Badan Rumah Sakit GKP \\ (email: annasusana1469@gmail.com )
}

\begin{abstract}
ABSTRAK:
Tujuan penelitian ini adalah untuk mengetahui praktik manajemen kesehatan peserta didik di Sekolah Dasar. Penelitian menggunakan pendekatan kualitatif dengan desain studi kasus di tiga Sekolah Dasar di Kota Sukabumi. Hasil penelitian secara umum menunjukkan bahwa penyelenggaraan usaha kesehatan bagi peserta didik Sekolah Dasar di Kota Sukabumi dapat terlaksana sebagai akibat dari konsistensi Pemerintah Daerah terhadap implementasi kebijakan baik secara organisasional melalui koordinasi antar institusi maupun secara operasional yang dilaksanakan di sekolah-sekolah. Keberhasilan penyelenggaraan usaha kesehatan bagi peserta didik di sekolah sangat tergantung dari proses manajemen yang dikembangkan di sekolah, mulai dari perencanaan, pengorganisasian, pelaksanaan/penggerakkan, dan pengendalian kegiatan usaha kesehatan di sekolah secara berkesinambungan. Berdasarkan hasil penelitian tersebut, maka sebagai alternatif dalam meningkatkan kinerja manajemen usaha kesehatan di sekolah peneliti merekomendasikan model hipotetik manajemen usaha kesehatan bagi peserta didik di Sekolah Dasar.
\end{abstract}

Kata kunci : Peserta Didik Sekolah Dasar, Proses Manajemen, Usaha Kesehatan Sekolah.

\section{ABSTRACT:}

The purpose of this research is to determine the health management practices of learners in elementary schools. The research used a qualitative approach with case study design in three elementary schools in Sukabumi City. The results of the study generally indicate that the implementation of health efforts for elementary school students in Sukabumi City can be implemented as a result of the consistency of local government towards the implementation of policies both organisasional through coordination between institutions and operational conducted in schools. Successful implementation of health efforts for students in schools depends on the management process developed in schools, from planning, organizing, implementing / mobilizing, and controlling health business activities in schools on an ongoing basis. Based on the results of the study, then as an alternative in improving the performance of health business management in school researchers recommend hypothetical model of health business management for learners in Elementary School.

Keywords: Elementary School Students, Management Process, School Health Effort.

\section{PENDAHULUAN}

Anak usia sekolah terdiri dari middle childhood (usia 6-10 tahun) dan early adolescence (usia 11-14 tahun). Usia anak sekolah dasar di Indonesia rata-rata berkisar antara $6-12$ tahun. Usia anak sekolah dasar ini termasuk dalam usia sekolah yang sangat rentan terhadap gangguan fisik, psikologis dan sosial karena anak sudah mulai berinteraksi secara lebih terbuka dengan lingkungan, teman sebaya dan orang-orang dewasa lainnya (termasuk guru). Dilain pihak anak belum sepenuhnya memiliki daya tangkal yang cukup baik secara fisik, psikososial dan spiritual dalam menentukan apa yang terbaik bagi dirinya. (Onis et al, 2007; Department of Education and Early Childhood Development-Victoria, 2012; UNESCO, 2012; Nurihsan, 2011).

Berdasarkan hasil-hasil penelitian yang telah dilakukan, proses pertumbuhan dan perkembangan anak serta faktor kesehatan anak akan sangat berpengaruh secara langsung maupun tidak langsung terhadap prestasi belajar anak. (Case Paxson, 2006; Hass \& Fosse, 2008; Basch, CE, 2010; Valois, R.F. Slade \& Ashford, 2011). Prestasi belajar dapat dilihat dari pencapaian akademik maupun non akademik. Prestasi akademik dapat diidentifikasi dari perolehan nilai di setiap mata pelajaran yang diberikan. Sedangkan prestasi non akademik dapat dilihat dari kemampuan afeksi dan psikomotorik yang dicapai peserta didik. Dengan kata lain prestasi peserta didik dapat dilihat dari outcome yang dihasilkan pendidikan yaitu dari pencapaian cognitive processing skills, emotional and social awareness and skills, and moral character development (Huitt, et al, 2009). Gangguan dalam proses pertumbuhan dan perkembangan anak akibat terpapar suatu penyakit, lingkungan yang buruk, kecelakaan, maupun pengaruh sosial yang tidak aman bagi anak akan mempengaruhi prestasi belajar anak. 
Selama di sekolah, anak berinteraksi dengan anak-anak lain, guru dan tenaga kependidikan dari berbagai latar belakang lingkungan yang berbeda dan kemungkinan akan mudah terpapar dengan berbagai penyakit menular. Demikian pula dengan kemungkinan terjadi cedera akibat aktivitas fisik yang sering dilakukan anakanak pada saat sekolah, seperti olah raga atau pada saat anak bermain. Selain itu, tidak menutup kemungkinan sekolah akan menerima anak-anak yang memiliki riwayat gangguan kesehatan kronis seperti Asthma, Diabetes Melitus, Penyakit Jantung dan lain-lain yang sewaktu-waktu terjadi serangan di sekolah. Oleh karena itu keberadaan pelayanan kesehatan di sekolah menjadi salah satu kebutuhan yang cukup penting dalam penyelenggaraan pendidikan di sekolah. (Case \& Paxson, 2006; Lear, 2007; Valois, R.F. Slade \& Ashford, 2011). Sekolah harus dapat menjamin ketersediaan lingkungan yang sehat, aman dan nyaman bagi setiap anak serta menyediakan layanan kesehatan komprehensif yang akan membantu setiap anak untuk tumbuh dan berkembang secara optimal. (Onis et al, 2007; Cetinkaya, 2009; UU RI No. 36 Tahun 2009 Tentang Kesehatan; Department of Education and Early Childhood Development-Victoria, 2012; UNESCO, 2012).

Kesadaran tentang pentingnya kesehatan bagi anak usia sekolah sudah digaungkan oleh WHO sejak tahun 1995 yang menginisiasi kesehatan sekolah secara global (global school health initiative). Tujuan dari inisiatif WHO ini adalah untuk memobilisasi dan menguatkan promosi dan pendidikan kesehatan di tingkat lokal, nasional, regional, bahkan global. Sasaran program adalah peserta didik, staf kependidikan di sekolah, keluarga (orang tua peserta didik) dan kelompok lain di masyarakat yang akan menyokong keberhasilan promosi kesehatan di sekolah. (WHO, 1996; WHO, 2000). Inisiasi WHO tentang promosi kesehatan di sekolah menjadi issue internasional yang menggerakkan negara-negara di dunia untuk mengembangkan promosi kesehatan di lingkungan sekolah.

Di Indonesia, usaha kesehatan di sekolah dilaksanakan dalam rangka mewujudkan UndangUndang No. 36 tahun 2009 tentang Kesehatan pasal 79 yang menyatakan bahwa usaha kesehatan sekolah diselenggarakan untuk meningkatkan kemampuan hidup sehat peserta didik dalam lingkungan hidup sehat sehingga peserta didik dapat belajar, tumbuh dan berkembang secara harmonis menjadi sumber daya manusia yang berkualitas. Untuk mencapai tujuan tersebut maka Pemerintah Indonesia mengeluarkan kebijakan pembinaan dan pengembangan usaha kesehatan sekolah yang dikelola secara bersama oleh 4 (empat) Kementerian yaitu : Menteri Pendidikan dan Kebudayaan, Menteri Kesehatan, Menteri Agama, dan Menteri Dalam Negeri melalui Peraturan Bersama 4 Menteri Nomor 6/X/PB/2014, Nomor 7 Tahun 2014, Nomor 41 Tahun 2014, dan Nomor 81 Tahun 2014 tentang Pembinaan dan Pengembangan Usaha Kesehatan Sekolah/Madrasah. Berdasarkan kebijakan tersebut, maka seluruh sekolah mulai TK/RA, SD/MI, SMP/MTs, dan SMA/SMK/MA beserta sekolah-sekolah Luar Biasa dari semua jenjang tersebut wajib melaksanakan usaha kesehatan di sekolah sesuai dengan pedoman yang telah ditetapkan secara nasional.

Keberhasilan Kota Sukabumi mempertahankan predikat sebagai "Kota UKS" sejak tahun 1996 hingga sekarang menunjukkan bahwa aspek-aspek yang dinilai dalam Lomba Sekolah Sehat dapat dipenuhi dengan baik. Hal-hal yang dinilai dalam Lomba Sekolah Sehat Tingkat Nasional, antara lain : (1) Penilaian terhadap Tim Pembina UKS tingkat Provinsi, Kabupaten/Kota, dan Kecamatan. Aspek yang dinilai meliputi kegiatan pembinaan UKS diantaranya pemantauan, pelatihan, dan keterlibatan sekolah; (2) Penilaian terhadap sekolah, dengan aspek yang dinilai antara lain kebersihan sarana/prasarana kelas, ruang guru, kantin, toilet, air bersih, tempat cuci tangan, tempat ibadah, kondisi tempat sampah, dan ruang UKS ; (3) Penilaian terhadap perilaku kesehatan peserta didik, diantaranya pengetahuan tentang UKS, perilaku hidup bersih dan sehat (PHBS); (4) Penilaian terhadap pelaksanaan pelayanan kesehatan, seperti pelaksanaan penjaringan kesehatan dan penyuluhan oleh petugas Puskesmas, dan lain-lain. (Kemenkes RI, 2013).

Melihat aspek penilaian dalam LSS sedemikian, maka diperlukan persiapan yang matang dari pihak sekolah, institusi-institusi yang terkait seperti Dinas Pendidikan dan Kebudayaan, Dinas Kesehatan, Pemerintah Daerah, dan unsurunsur lain yang turut berkontribusi dalam penyelenggaraan sekolah sehat yang diharapkan. Untuk mengakomodasi kebutuhan penyelenggaraan upaya kesehatan peserta didik di sekolah, juga diperlukan suatu konsep pengembangan organisasi (organizational development) yang mampu mengungkit semua unsur yang ada untuk mencapai tujuan yang diharapkan. Pengembangan organisasi adalah suatu proses yang diaplikasikan berdasarkan ilmu perilaku yang membantu organisasi membangun kapasitasnya untuk berubah dan untuk mencapai efektivitas organisasi. Pengembangan organisasi di 
sekolah diawali dari kekuatan rencana perubahan, khususnya proyek manajemen atau inovasi yang membangun kemampuan organisasi sekolah dari kondisi sekarang untuk mencapai tujuan yang diharapkan. Pengembangan organisasi berorientasi pada peningkatan sistem secara total, oleh karena itu fungsi penting dalam pengembangan organisasi adalah efektivitas proses manajemen yang dijalankan. (Wahab, 2011).

Proses manajemen akan berjalan baik jika fungsi-fungsi manajemen berjalan secara sinergi. Fungsi-fungsi manajemen tersebut adalah perencanaan (planning), pengorganisasian (organizing), pelaksanaan dan kepemimpinan (leading), dan pengawasan (controling) atau lebih dikenal dengan istilah POLC framework (Carpenter \& Sanders, 2009). Keberhasilan usaha kesehatan peserta didik di sekolah tidak terlepas dari sejauhmana fungsi-fungsi manajemen tersebut dapat dijalankan dan bersinergi dengan program pembelajaran secara umum di sekolah. Penyelenggaraan usaha kesehatan peserta didik di sekolah secara holistik terdiri dari pengelolaan status kesehatan peserta didik, penyediaan infrastruktur dan lingkungan sekolah yang sehat dan aman, serta kolaborasi multidisiplin dari lintas institusional untuk menyelenggarakan pelayanan kesehatan secara holistik. (Fowler, 2004; Fowler \& Dell, 2005; Department Of Defense Education Activity, 2007; Onis et al, 2007; Cetinkaya, 2009; Foster Social Development In Early Childhood, 2009; ; State Government Victoria. Departemen of Education and Early Childhood Development, 2012; UNESCO, 2012).

Berdasarkan hasil studi pendahuluan yang dilakukan oleh Peneliti di Kota Sukabumi diperoleh keterangan bahwa Pemerintah Daerah Kota Sukabumi dalam hal ini Tim Pembina UKS Kota Sukabumi telah menetapkan strata UKS yang disesuaikan dengan kondisi dan kemampuan sekolah dalam penyelenggaraan UKS-

Data tersebut menunjukkan bahwa hampir seluruh sekolah yang ada di Kota Sukabumi $(98,88 \%)$ telah melaksanakan UKS. Dari sekolah yang sudah melaksanakan UKS sebagian besar $(62,88 \%)$ masuk dalam strata standar, optimal dan paripurna. Artinya sebagian besar sudah melaksanakan Trias UKS sesuai dengan standar yang ditetapkan berdasarkan Hasil Rapat Kerja Nasional UKS (2004). Sekolah Dasar/Madrasah Ibtidaiyah merupakan lembaga pendidikan terbanyak yang ada di Kota Sukabumi dan seluruhnya $(100 \%)$ telah melaksanakan UKS.

Berdasarkan latar belakang tersebut, Peneliti ingin memperoleh gambaran secara lengkap tentang sejauhmana sekolah-sekolah, khususnya Sekolah Dasar di Kota Sukabumi dapat berhasil mengelola usaha kesehatan bagi peserta didik di sekolah serta bagaimana dampak pelaksanaan UKS terhadap peningkatan derajat kesehatan dan perubahan perilaku hidup sehat yang akan menyokong pencapaian prestasi peserta didik secara optimal.

Kerangka pemikiran dalam penelitian ini didasarkan atas pemahaman bahwa kesehatan yang paripurna (holistik) adalah salah satu faktor yang mendukung keberhasilan seseorang (individu) dalam mencapai prestasi melalui proses belajar mengajar yang ditempuhnya. (Paxson, 2006; Hass \& Fosse, 2008; Basch. CE, 2010; Valois. Robert. F, 2011). Kesehatan seseorang di masa awal kehidupan sampai usia sekolah merupakan aspek penting dalam kelangsungan seseorang untuk berprestasi di jenjang pendidikan selanjutnya (Hass \& Fosse, 2008). Dalam penelitian ini difokuskan pada anak usia sekolah, dimana usia ini merupakan usia dimulainya seseorang untuk berinteraksi dengan lingkungan yang lebih luas dari orang tua dan keluarganya. Di usia ini anak sudah banyak mendapatkan tantangan dari lingkungan sekitar dan orang-orang di luar keluarganya, termasuk diataranya adalah teman sebaya, guru dan orang dewasa lainnya. (Mc.Devitt \& Ormrod, 2002; Fowler, 2004; Fowler \& Dell, 2005; Onis et al, 2007; Cetinkaya, 2009; Foster Social Developmen In Early Childhood, 2009; Papalia et al, 2010; Desmita, 2012).

Gangguan dalam proses pertumbuhan dan perkembangan anak akibat terpapar suatu penyakit, lingkungan yang buruk, kecelakaan, maupun pengaruh sosial yang tidak aman bagi anak akan mempengaruhi prestasi belajar anak. Oleh karena itu sekolah harus dapat menjamin ketersediaan lingkungan yang sehat, aman dan nyaman bagi setiap anak serta menyediakan layanan kesehatan komprehensif yang akan membantu setiap anak untuk tumbuh dan berkembang secara optimal. (Onis et al, 2007; Cetinkaya, 2009; UU RI No. 36 Tahun 2009 Tentang Kesehatan; Department of Education and Early Childhood DevelopmentVictoria, 2012; UNESCO, 2012). Sekolah sebagai sistem sosial terbuka dipengaruhi oleh lingkungan secara luas dan sebaliknya (Hoy \& Miskel, 2008) merupakan lembaga potensial bagi anak usia sekolah untuk tumbuh dan berkembang secara optimal. Sekolah menyediakan sumber daya manusia, lingkungan dan sarana prasarana juga sistem manajemen sekolah (budaya sekolah) yang mampu mengakomodasi kebutuhan anak untuk mampu beradaptasi, berprestasi dan mengintegrasikan berbagai ilmu pengetahuan dasar untuk kepentingan masa depannya. 
Keberadaan dukungan masyarakat di sekitar sekolah akan sangat membantu sekolah dalam menciptakan lingkungan pendidikan yang kondusif bagi peserta didik. Dukungan masyarakat dapat berupa keterlibatan anggota masyarakat (komite sekolah) terhadap proses pembelajaran di sekolah termasuk program usaha kesehatan bagi peserta didik di sekolah. Selain itu masyarakat juga menyediakan pendidikan pra sekolah yang membantu peserta didik untuk lebih cepat beradaptasi dengan aktivitas pembelajaran dan lingkungan sosial sekolah. Dukungan masyarakat juga berupa ketersediaan sarana pelayanan kesehatan di sekitar sekolah yang akan menyokong keterlaksanaan usaha kesehatan bagi peserta didik di sekolah.

Upaya kesehatan peserta didik di sekolah terdiri dari pelaksanaan pendidikan kesehatan, pemeriksaan status kesehatan peserta didik, penyediaan infrastruktur dan lingkungan sekolah yang sehat. Untuk keberhasilan pengelolaan kesehatan peserta didik di sekolah diperlukan komitmen yang kuat dari setiap unsur yang terlibat, terutama dari pemerintah. Pemerintah menyediakan kebijakan-kebijakan dan legalitas yang mendasari penyelenggaraan upaya kesehatan peserta didik di sekolah. (Fowler, 2004; Fowler \& Dell, 2005; Department Of Defense Education Activity, 2007; Onis et al, 2007; Cetinkaya, 2009; Foster Social Development In Early Childhood, 2009; Valois, R.F. Slade \& Ashford, 2011; State Government Victoria. Departemen of Education and Early Childhood Development, 2012; UNESCO, 2012).
Sebagai wujud implementasi kebijakan usaha kesehatan peserta didik di sekolah serta untuk mengakomodasi penyelenggaraan upaya kesehatan peserta didik di sekolah, diperlukan suatu konsep pengembangan organisasi (organizational development) yang mampu mengungkit semua unsur yang ada untuk mencapai tujuan yang diharapkan. Pengembangan organisasi diawali dari kekuatan rencana perubahan, khususnya proyek manajemen atau inovasi yang membangun kemampuan organisasi dari kondisi sekarang untuk mencapai tujuan yang diharapkan.(McLean. Gary. N, 2005; Gazaryan. Wahab, 2011). Penyelenggaraan upaya kesehatan di sekolah perlu dikelola dengan sistematis melalui pelaksanaan fungsi-fungsi manajemen (perencanaan, pengorganisasian, pelaksanaan, dan pengendalian).

Hasil dari penyelenggaraan usaha kesehatan peserta didik di sekolah diharapkan bahwa peserta didik akan memperoleh jaminan pemeliharaan kesehatan secara terstruktur, mendapatkan pendidikan dan keterampilan yang terkait dengan pola hidup sehat, dan mendapatkan sarana dan lingkungan yang sehat di sekolah sehingga proses belajar mengajar lebih kondusif. Kesemua aspek tersebut adalah dalam rangka meningkatkan derajat kesehatan peserta didik secara holistik. Dengan kesehatan yang prima, peserta didik akan berpotensi untuk mengikuti proses belajar mengajar secara optimal dan menunjukkan prestasi belajar yang memuaskan baik secara akademik maupun non akademik. Secara ringkas kerangka pikir penelitian digambarkan sebagai berikut :

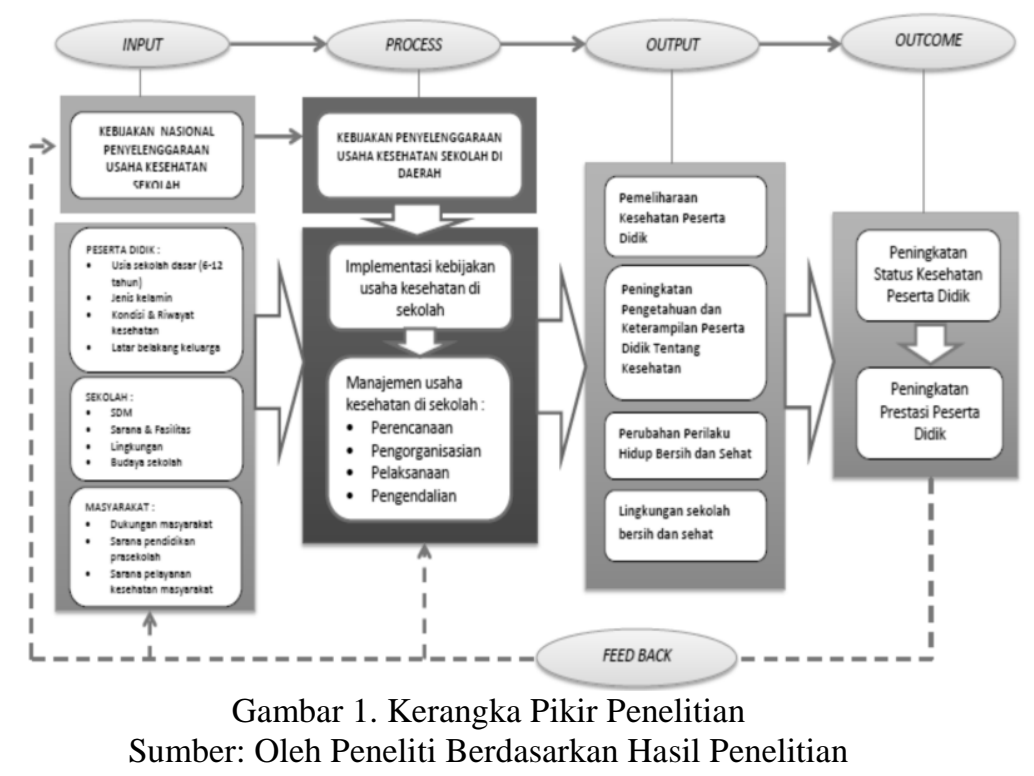


Penelitian ini menggunakan pendekatan kualitatif. Sedangkan strategi penelitian yang dipergunakan adalah dengan studi kasus. Pendekatan kualitatif dengan metode studi kasus digunakan untuk mengkaji dan menjawab permasalahan, serta menemukan, dan memperoleh makna yang lebih mendalam tentang Manajemen Kesehatan Peserta didik di Sekolah Dasar, dalam hal ini studi kasus di SDN Suryakencana CBM, SDN Dewi Sartika CBM dan SDN Sukasirna Kota Sukabumi.

Unit analisis dari penelitian ini adalah situasi sosial dimana proses manajemen usaha kesehatan peserta didik Sekolah Dasar di Kota Sukabumi dilaksanakan. Sumber data yang diperlukan sesuai dengan unit analisis penelitian ini ditentukan secara purposive, yaitu ditentukan dengan menyesuaikan pada tujuan penelitian. Pengumpulan data diperoleh dari hasil wawancara, studi dokumentasi dan obervasi kegiatan yang berkaitan dengan usaha kesehatan di sekolah secara langsung.

Proses penelitian diawali dengan pengamatan peneliti terhadap fenomena yang terjadi dalam penyelenggaraan usaha kesehatan di sekolah dari berbagai literatur, observasi langsung di sekolah-sekolah dan pemberitaan di media massa. Kemudian peneliti mengembangkan asumsi penelitian dan menegaskan/menjelaskan ranah yang akan diteliti dari fenomena yang diamati peneliti. Dalam tahap ini, Peneliti juga melakukan penguatan dari literatur, konsep-konsep dan hasil penelitian terdahulu yang selaras dengan penyelenggaraan usaha kesehatan bagi peserta didik di sekolah. Peneliti melakukan pemilihan objek penelitian dengan melakukan studi pendahuluan yang diawali dengan studi dokumentasi dari laporan-laporan penyelenggaraan UKS, Kebijakan Pemerintah terkait penyelenggaraan UKS, pemberitaan di media cetak maupun internet terkait hasil lomba sekolah sehat baik tingkat Provinsi maupun tingkat Nasional, dan pedoman-pedoman penyelenggaraan UKS yang dikeluarkan oleh Kementerian Pendidikan dan Kebudayaan maupun Kementerian Kesehatan. Selanjutnya Peneliti melakukan observasi langsung ke Kota Sukabumi.

Peneliti melakukan tahapan penelitian dengan mengumpulkan data secara intensif terhadap faktor kebijakan penyelenggaraan UKS di Kota Sukabumi yang meliputi rumusan, strategi, implementasi dan evaluasi kebijakan. Selanjutnya, peneliti melakukan pengumpulan data terkait dengan proses manajemen kesehatan peserta didik di sekolah sebagai implementasi kebijakan secara operasional, yang meliputi : pelaksanaan fungsifungsi manajemen (perencanaan, pengorganisasian, pelaksanaan dan pengendalian), sistem koordinasi, pendanaan dan sistem informasi manajemen yang dilaksanakan serta dampak usaha kesehatan peserta didik terhadap pencapaian prestasi. Pengumpulan data dilakukan dengan wawancara mendalam dengan nara sumber/partisipan sesuai kebutuhan penelitian, studi dokumentasi dan observasi kegiatan-kegiatan UKS di sekolah/lokasi yang ditetapkan.

Peneliti melakukan triangulasi sumber data untuk menghindari bias yang diperoleh dari hasil wawancara, studi dokumentasi dan observasi, serta lebih memfokuskan kepada aspek operasional manajemen kesehatan peserta didik di sekolah. Seiring dengan proses tersebut, Peneliti melakukan analisis dan validasi data dari berbagai sumber secara terintegrasi. Hasil pengolahan data kemudian dirangkum/disimpulkan dan menjadi masukan untuk menjawab pertanyaan-pertanyaan penelitian. Tahap akhir peneliti mengusulkan Model Hipotetik Manajemen Kesehatan Peserta Didik di Sekolah Dasar sesuai dengan hasil penelitian.

\section{HASIL PENELITIAN DAN PEMBAHASAN}

\section{Hasil Penelitian}

Secara umum temuan hasil penelitian menunjukkan bahwa penyelenggaraan usaha kesehatan bagi peserta didik Sekolah Dasar di Kota Sukabumi dapat terlaksana sebagai akibat dari konsistensi pemerintah daerah terhadap implementasi kebijakan baik secara organisasional melalui koordinasi lintas institusi maupun secara operasional yang dilaksanakan di sekolah-sekolah. Keberhasilan penyelenggaraan usaha kesehatan bagi peserta didik di sekolah sangat tergantung dari proses manajemen yang dikembangkan di sekolah, mulai dari perencanaan, pengorganisasian, pelaksanaan/ penggerakkan, dan pengendalian kegiatan usaha kesehatan di sekolah.

Temuan penelitian secara khusus menunjukkan bahwa :

1. Penyelenggaraan usaha kesehatan bagi peserta didik di sekolah merupakan implementasi dari kebijakan yang telah ditetapkan oleh Pemerintah secara terpusat. Pemerintah daerah memiliki otonomi dalam menetapkan 
kebijakan daerah terkait penyelenggaraan usaha kesehatan di sekolah sesuai dengan kebutuhan kesehatan peserta didik di daerahnya.

2. Keberhasilan penyelenggaraan usaha kesehatan bagi peserta didik di sekolah sangat tergantung dari proses manajemen yang dikembangkan di sekolah, mulai dari perencanaan, pengorganisasian, pelaksanaan/penggerakkan, dan pengendalian kegiatan usaha kesehatan di sekolah secara berkesinambungan.

a. Perencanaan yang baik dan terarah dapat menentukan tingkat keberhasilan program usaha kesehatan di sekolah. Ketidakjelasan indikator hasil dalam perencanaan berdampak pada kesulitan dalam menetapkan tingkat keberhasilan program.

b. Pengorganisasian yang tepat membantu kelancaran penyelenggaraan program usaha kesehatan di sekolah. Ketersediaan sumber daya manusia yang memadai serta kesiapan seluruh unsur sekolah dalam mendukung pelaksanaan program usaha kesehatan di sekolah sangat menentukan keberhasilan program.

c. Keberhasilan pelaksanaan program usaha kesehatan di sekolah tergantung pada kepemimpinan Kepala Sekolah dan komitmen seluruh unsur sekolah untuk mendukung pelaksanaan program.

d. Pengendalian program usaha kesehatan di sekolah dilaksanakan dengan upaya pengawasan, evaluasi dan penilaian. Kelemahan dalam menetapkan program kerja beserta indikator keberhasilan berdampak pada kesulitan dalam menilai keberhasilan program serta menetapkan tindak lanjut program.

3. Koordinasi lintas institusi dalam penyelenggaraan usaha kesehatan bagi peserta didik di sekolah dimotori dan digerakkan oleh Pemerintah Daerah sesuai dengan kebutuhan pengembangan usaha kesehatan di sekolah.

4. Penyelenggaraan usaha kesehatan peserta didik di sekolah didanai oleh Pemerintah. Sekolah memiliki otoritas dalam mengelola dan mengusahakan pendanaan usaha kesehatan peserta didik di sekolah.

5. Penggunaan sistem informasi manajemen kesehatan peserta didik (SIMKesdik) di sekolah membantu dalam proses pengendalian data kesehatan peserta didik secara berkesinambungan mulai dari pengumpulan data, pendokumentasian, pelaporan dan pengambilan keputusan untuk tindak lanjut kegiatan usaha kesehatan peserta didik di sekolah.

6. Dampak dari usaha kesehatan bagi peserta didik di sekolah terlihat secara nyata dari pemantauan kesehatan peserta didik secara periodik, perubahan perilaku hidup sehat, peningkatan pengetahuan akan kesehatan, dan lingkungan sekolah tetap bersih dan sehat yang kesemuanya akan berdampak bagi peningkatan derajat kesehatan dan mendukung pencapaian prestasi belajar peserta didik.

Dari hasil penelitian di atas ditemukan pula beberapa ketidaksesuaian yang menjadi perhatian peneliti, yaitu:

1. Aspek kebijakan

a. Dalam pengendalian kebijakan penyelenggaraan usaha kesehatan peserta didik di sekolah kurang diperhatikan tindak lanjut pengembangan kegiatan UKS di sekolah-sekolah ex-juara LSS, sehingga banyak fasilitas UKS di sekolah-sekolah tersebut tidak terpelihara dengan baik.

b. Mekanisme sistem pelaporan kegiatan UKS dari sekolah-sekolah ke Tim Pembina UKS (Kecamatan maupun Kota) tidak didukung oleh dokumentasi yang sistematis. Hal ini menyebabkan adanya kesulitan dalam menilai tingkat keberhasilan pelaksanaan kebijakan penyelenggaraan UKS di Kota Sukabumi.

c. Kebijakan penyelenggaraan usaha kesehatan di sekolah belum berdampak secara nyata pada perubahan perilaku hidup sehat di masyarakat sekitar sekolah.

2. Aspek proses manajemen usaha kesehatan peserta didik di sekolah

a. Fungsi perencanaan

1) Rumusan program kerja UKS menggunakan format baku yang ditetapkan oleh Tim Pembina UKS Kota, tidak menunjukkan indikator keberhasilan dari setiap kegiatan yang direncanakan. Hal ini akan menyulitkan Tim Pelaksana UKS di sekolah untuk menilai pencapaian keberhasilan program setelah dilaksanakan.

2) Uraian kegiatan program UKS lebih menitikberatkan pada aspek kesehatan secara fisik. Kegiatan-kegiatan dari aspek kesehatan psikososial dan spiritual tidak tampak dalam program

b. Fungsi pengorganisasian

1) Kendala utama dalam pengorganisasian usaha kesehatan di skeolaha dalah keterbatasan SDM 
(baik dari Guru Pembina UKS maupun dari tenaga kesehatan Puskesmas), sehingga banyak kegiatan yang tidak dapat terlaksanakan sesuai program.

c. Fungsi pelaksanaan

1) Akibat dari terbatasnya SDM, maka banyak program UKS tidak bisa dilaksanakan sesuai program.

2) Pelaksanaan pelayanan kesehatan bagi peserta didik terbatas pada kegiatan Puskesmas yang sudah rutin dijalankan yaitu penjaringan kesehatan, immunisasi, pemberantasan penyakit menular, penyuluhan kesehatan dan pemberian suplemen/makanan tambahan.

d. Fungsi pengendalian

1) Kegiatan pengendalian yang dilakukan oleh Tim Pelaksana UKS di sekolah tidak terdokumentasi dengan baik, sehingga sulit menilai perkembangan program yang sudah dilaksanakan.

2) Tim Pelaksana UKS tidak membuat laporan kegiatan UKS seperti yang seharusnya dilakukan kepada Tim Pembina UKS.

3) Terdapat kesenjangan yang cukup besar antara program kerja dengan indikator keberhasilan program yang ditetapkan oleh pemerintah (pedoman pelaksanaan UKS di sekolah).

e. Aspek koordinasi lintas institusi

1) Pelaksanaan koordinasi lintas institusi dalam penyelenggaraan UKS di Kota Sukabumi sangat intensif pada saat pelaksanaan kegiatan-kegiatan yang diinsiasi oleh Tim Pembina UKS Kota/Kecamatan seperti LSS dan Jambore UKS. Di luar kegiatan tersebut terbatas hanya sekolah dengan Puskesmas untuk melaksanakan kegiatan pelayanan kesehatan yang secara rutin dilaksanakan.

f. Aspek penggunaan sistem informasi manajemen kesehatan peserta didik

1) Sekolah tidak memiliki dokumentasi data kesehatan peserta didik secara lengkap dan berkesinambungan. Perkembangan kesehatan peserta didik tidak diketahui.

2) Mekanisme pelaporan data kesehatan peserta didik hasil penjaringan kesehatan dilakukan oleh Puskesmas. Tidak ada feedback hasil pemeriksaan kesehatan terhadap orang tua peserta didik untuk tindak lanjut pelayanan kesehatan.

\section{Pembahasan}

1. Kebijakan Daerah Dalam Penyelenggaraan Usaha Kesehatan Peserta Didik Sekolah Dasar. Kebijakan penyelenggaraan UKS yang sejak semula melibatkan 4 Kementerian, yaitu Kementerian Kesehatan, Kementerian Pendidikan dan Kebudayaan, Kementerian Agama, dan Kementerian Dalam Negeri merupakan suatu peluang sekaligus tantangan bagi setiap institusi tersebut. Kolaborasi empat kementerian yang dirancang secara hirarkis dari pusat ke daerah, serta melibatkan pejabat-pejabat utama di setiap jenjang pemerintahan memerlukan pemahaman yang seimbang dari setiap pejabat yang terlibat. Hal ini tidaklah mudah mengingat dinamika pemerintahan Indonesia saat ini terus berkembang dan seringkali berubah. Berdasarkan hasil penelitian yang telah dilakukan di Kota Sukabumi, ditemukan bahwa secara umum penyelenggaraan UKS dapat dilaksanakan oleh karena adanya komitmen bersama yang dimotori secara langsung oleh Pemerintah Daerah setempat untuk mendukung penyelenggaraan UKS di setiap sekolah. Pemerintah Daerah Kota Sukabumi mengambil porsi yang dominan dalam menetapkan kebijakan penyelenggaraan UKS di Kota Sukabumi, sehingga setiap unsur pemerintahan dan aparat pemerintah dari berbagai sektor dapat menjalankan kegiatan sesuai dengan kebijakan yang ditetapkan oleh Pemerintah Daerah tersebut.

Perumusan kebijakan penyelenggaraan usaha kesehatan sekolah didasarkan pada adanya kesadaran untuk meningkatkan kesejahteraan masyarakat yang secara spesifik ditujukan kepada masyarakat sekolah untuk mempersiapkan generasi yang sehat, cerdas dan sejahtera. Dengan melihat hasil kajian kondisi nyata di masyarakat maka kebijakan penyelenggaraan usaha kesehatan sekolah dirumuskan untuk memperbaiki dan mengoreksi kekurangan yang masih dirasakan, serta memperkuat dan mengembangkan potensi yang sudah ada menjadi lebih optimal untuk kepentingan masyarakat luas.

Formulasi kebijakan penyelenggaraan usaha kesehatan sekolah menghasilkan suatu strategi yang dijadikan acuan dan pedoman untuk melaksanakan kebijakan di tingkat organisasional maupun operasional. Pelaksanaan kebijakan di tingkat organisasional dilaksanakan oleh Tim Pembina UKS dalam rangka pembinaan dan pengembangan usaha kesehatan sekolah, sedangkan di tingkat operasional dilaksanakan oleh 
satuan pendidikan, dimana sasaran utamanya adalah peserta didik.

Pelaksanaan kebijakan usaha kesehatan peserta didik di sekolah merupakan proses yang sangat penting dalam menilai keberhasilan kebijakan tersebut. Pelaksanaan kebijakan akan berhasil dengan baik apabila kebijakan dipahami secara jelas oleh pelaku kebijakan dalam hal ini adalah Tim Pembina UKS dan Tim Pelaksana UKS di sekolah, dan sebaliknya pembuat kebijakan perlu mengetahui secara pasti sasaran kebijakan dan masalah-masalah yang terjadi di lokasi kebijakan tersebut akan dilaksanakan. Sosialisasi kebijakan sangat penting dalam rangka memberikan pemahaman akan tujuan dan manfaat kebijakan secara khusus untuk meningkatkan derajat kesehatan peserta didik, dan secara umum untuk meningkatkan kesadaran berperilaku hidup sehat di lingkungan sekolah dan masyarakat. Dukungan dari pemerintah atau pimpinan institusi dalam pelaksanaan kebijakan sangat dibutuhkan untuk menggerakkan sumber daya yang ada untuk mendukung keberhasilan kebijakan yang dilaksanakan.

Pengendalian kebijakan penyelenggaraan usaha kesehatan peserta didik di sekolah perlu dilakukan secara terus menerus dengan melakukan pelaporan, evaluasi dan supervisi secara berkesinambungan untuk memastikan proses kebijakan dilaksanakan di lapangan serta menilai tingkat keberhasilan kebijakan yang diberlakukan.

Kebijakan usaha kesehatan peserta didik di sekolah diharapkan berdampak bagi peningkatan derajat kesehatan peserta didik dan terjadinya perubahan perilaku hidup bersih dan sehat di kalangan peserta didik. Dengan meningkatnya derajat kesehatan peserta didik diharapkan dapat berdampak pada peningkatan potensi untuk belajar dengan baik dan menjadi insan yang cerdas, berdaya saing tinggi dan dapat memberikan sumbangsih dalam pembangunan bangsa.

2. Proses Manajemen Usaha Kesehatan Peserta Didik di Sekolah Dasar

Pada dasarnya proses manajemen usaha kesehatan peserta didik di sekolah merupakan implementasi secara operasional dari kebijakan penyelenggaraan usaha kesehatan peserta didik yang telah ditetapkan oleh pemerintah. Pengelolaan usaha kesehatan peserta didik di sekolah tidak semata-mata hanya melaksanakan amanat kebijakan pemerintah, tetapi harus disadari bahwa aspek kesehatan peserta didik merupakan aspek yang penting dalam menunjang kelancaran proses pendidikan peserta didik di sekolah. Aspek kesehatan merupakan kebutuhan individu dari setiap peserta didik yang harus diperhatikan ketika peserta didik berada di lingkungan sekolah.

Keberhasilan usaha kesehatan peserta didik di sekolah tidak terlepas dari sejauhmana fungsifungsi manajemen mulai dari planning, organizing, leading dan controling dapat dijalankan dan bersinergi dengan program pembelajaran secara umum di sekolah. Penyelenggaraan usaha kesehatan peserta didik di sekolah secara holistik terdiri dari pengelolaan status kesehatan peserta didik, penyediaan infrastruktur dan lingkungan sekolah yang sehat, serta kolaborasi multidisiplin dari lintas institusional untuk menyelenggarakan pelayanan kesehatan secara holistik. (Fowler, 2004; Fowler \& Dell, 2005; Department Of Defense Education Activity, 2007; Onis et al, 2007; Cetinkaya, 2009; Foster Social Development In Early Childhood, 2009; Valois. Robert. F, 2011; State Government Victoria. Departemen of Education and Early Childhood Development, 2012; UNESCO, 2012).

Perencanaan usaha kesehatan peserta didik di sekolah diawali dengan adanya kajian akan kebutuhan dan keinginan untuk mewujudkan peserta didik yang sehat dan cerdas. Keinginan tersebut dituangkan dalam visi dan misi sekolah sebagai pernyataan komitmen seluruh warga sekolah untuk menyelenggarakan usaha kesehatan bagi peserta didik di sekolah. Tujuan yang ingin dicapai dalam penyelenggaraan usaha kesehatan peserta didik di sekolah dijabarkan dalam strategi penyelenggaraan, diantaranya adalah dengan pengembangan kurikulum untuk mengakomodasi kegiatan usaha kesehatan peserta didik dalam program kurikuler dan ekstrakurikuler. Program kerja disusun dengan mempertimbangkan kemampuan dan potensi yang ada di sekolah serta dukungan dari multidisiplin lintas institusi untuk memenuhi kebutuhan kesehatan peserta didik secara komprehensif.

Pengorganisasian usaha kesehatan peserta didik di sekolah merupakan proses yang dilakukan untuk mengatur sumber daya yang dimiliki oleh sekolah untuk melaksanakan sejumlah kegiatan dalam rangka mencapai tujuan yaitu meningkatkan taraf kesehatan peserta didik dan membangun kebiasaan hidup bersih dan sehat. Pengorganisasian sumber daya manusia di sekolah harus diatur sedemikan rupa supaya tidak tumpang tindih dengan kegiatan lain di sekolah. Peran petugas kesehatan sangat dominan dalam pelaksanaan pelayanan kesehatan secara komprehensif melalui kegiatan promotif, preventif, kuratif dan rehabilitatif di sekolah, oleh karena itu keberadaan tenaga kesehatan profesional seperti perawat kesehatan perlu difikirkan sebagai 
jalan keluar untuk meningkatkan kontinuitas pelayanan kesehatan kepada peserta didik. Keterlibatan berbagai pihak lintas institusi dan masyarakat secara luas dalam penyelenggaraan usaha kesehatan di sekolah menuntut Kepala Sekolah untuk lebih proaktif dalam mensosialisasikan program usaha kesehatan sekolah dan membangun kerjasama lintas institusi dan mengembangkan kerjasama dengan lembagalembaga masyarakat yang efektif dan efisien.

Pelaksanaan usaha kesehatan bagi peserta didik di sekolah harus disesuaikan dengan kebutuhan kesehatan peserta didik secara holistik yaitu mencakup kebutuhan kesehatan fisik, psikologis, sosial dan spiritual. Pelaksanaan kegiatan usaha kesehatan di sekolah dapat terselenggara dengan baik jika semua unsur sekolah dan pendukung dari luar institusi berkomitmen melaksanakannya sesuai dengan program yang sudah ditetapkan. Peran kepemimpinan kepala sekolah dalam menggerakkan dan memotivasi seluruh unsur sekolah untuk melaksanakan kegiatan akan sangat besar pengaruhnya bagi keberhasilan pelaksanaan usaha kesehatan bagi peserta didik di sekolah.

Pengendalian kegiatan usaha kesehatan bagi peserta didik di sekolah meliputi upaya monitoring dan evaluasi yang didukung oleh pencatatan dan pelaporan untuk melihat, menilai dan memastikan pelaksanaan kegiatan usaha kesehatan bagi peserta didik di sekolah. Pengendalian dilaksanakan secara periodik dan berkesinambungan, salah satu cara yang dipergunakan Pemerintah (Daerah) dalam memonitor dan mengevaluasi keterlaksanaan kegiatan usaha kesehatan di sekolah adalah dengan menyelenggarakan lomba sekolah sehat secara berjenjang mulai dari tingkat Kecamatan, Kota/Kabupaten, Provinsi bahkan tingkat Nasional yang diadakan setiap tahun.

3. Koordinasi Antar Institusi Dalam

Penyelenggaraan Usaha Kesehatan Peserta

Didik di Sekolah Dasar.

Koordinasi multidisiplin lintas institusi dalam penyelenggaraan usaha kesehatan di sekolah pada dasarnya adalah untuk memenuhi kebutuhan kesehatan peserta didik secara holistik. Unsurunsur yang terlibat dalam koordinasi usaha kesehatan peserta didik adalah unsur yang akan mampu memberikan kontribusi dalam mewujudkan kebutuhan tersebut. Pemenuhan kebutuhan kesehatan peserta didik meliputi kebutuhan kesehatan secara fisik, psikologis, sosial dan spiritual juga melengkapi kebutuhan sarana prasarana serta lingkungan sekolah yang sehat dan kondusif serta kebijakan-kebijakan yang diperlukan untuk mendukung pemenuhan kebutuhan tersebut.

4. Pendanaan Usaha Kesehatan Peserta Didik

\section{Sekolah Dasar}

Pendanaan usaha kesehatan peserta didik di sekolah merupakan tanggung jawab pemerintah yang dikelola oleh sekolah dengan prinsip manajemen berbasis sekolah. Sekolah secara otonomi berhak mengelola keuangan dan dana yang tersedia sesuai dengan kebutuhan penyelenggaraan usaha kesehatan peserta didik di sekolah dan mengembangkan usaha kemitraan dengan lembaga-lembaga di masyarakat untuk mendukung pendanaan sepanjang dapat dipertanggungjawabkan dengan baik.

\section{Implementasi Sistem Informasi Manajemen}

Kesehatan Peserta Didik Sekolah Dasar.

Hasil penelitian yang dilaksanakan terkait penggunaan sistem informasi manajemen kesehatan peserta didik (SIMKesdik) di Sekolah Dasar Kota Sukabumi secara umum membuktikan bahwa dengan bantuan perangkat komputer pengelolaan kesehatan peserta didik di sekolah dapat dilaksanakan lebih efektif dan efisien. Hasil penelitian tersebut sesuai dengan gambaran yang dikemukakan oleh Laudon \& Laudon (2007) bahwa sistem informasi manajemen berbasis komputer secara umum dapat meningkatkan proses bisnis melalui dua cara yaitu : (1) meningkatkan efisiensi proses bisnis karena meningkatnya koordinasi, dihindarinya duplikasi dan dipercepatnya proses sehingga menghemat waktu; (2) mengubah proses bisnis dalam wujud mengubah bentuk produk menjadi digital, dan mengubah prosedur menjadi lebih memudahkan.

Penggunaan sistem informasi manajemen kesehatan peserta didik dapat meningkatkan kinerja Tim Pelaksana UKS di sekolah dalam mengelola data kesehatan peserta didik mulai dari pendokumentasian data kesehatan secara kontinue, pemrosesan data menjadi laporan dan meningkatkan kecepatan dalam pengambilan keputusan karena terjadi penyederhanaan tugas dan alur proses pelaporan mulai dari Tim Pelaksana di sekolah sampai Tim Pembina UKS yang berada di Kecamatan, Kota/Kabupaten, Provinsi sampai Pusat.

6. Dampak Usaha Kesehatan Peserta Didik Di Sekolah Terhadap Pencapaian Prestasi Peserta Didik Sekolah Dasar.

Aspek kesehatan akan mempengaruhi pencapaian prestasi peserta didik secara langsung maupun tidak langsung, karena faktor kesehatan akan memberikan dukungan terhadap 
stamina/kebugaran fisik anak untuk mengikuti kegiatan sesuai usia berkembangannya, memberikan dorongan untuk bergerak secara aktif, dan meningkatkan motivasi untuk mempelajari sesuatu sesuai usia berkembangannya. Pernyataan tersebut sama dengan pernyataan yang diungkapkan oleh beberapa penulis dan peneliti terdahulu (Case Paxson, 2006; Hass \& Fosse, 2008; Basch. CE, 2010; Valois, R.F. Slade \& Ashford, 2011) yang menyatakan bahwa proses pendidikan dapat ditempuh dan dilaksanakan dengan optimal apabila peserta didik berada dalam kondisi memadai baik secara fisik, psikologis, sosial maupun moral spiritual.

Dampak usaha kesehatan terhadap pencapaian prestasi peserta didik dilihat dari aspek potensi kesehatan yang dimiliki peserta didik, pembiasaan hidup bersih dan sehat serta pencapaian prestasi peserta didik di sekolah dan di luar sekolah. Potensi kesehatan peserta didik berupa latar belakang keluarga, riwayat kesehatan dan kondisi kesehatan peserta didik mempengaruhi terhadap kuantitas dan kualitas keikutsertaan peserta didik dalam kegiatan pembelajaran di sekolah yang akhirnya mempengaruhi pencapaian prestasi peserta didik. Kebiasaan hidup bersih dan sehat mulai ditunjukkan peserta didik karena adanya pembiasaan dan keteladanan di lingkungan sekolah. Pencapaian prestasi peserta didik ditentukan oleh minat dan bakat serta pengaruh orang tua, guru dan lingkungan sekolah.

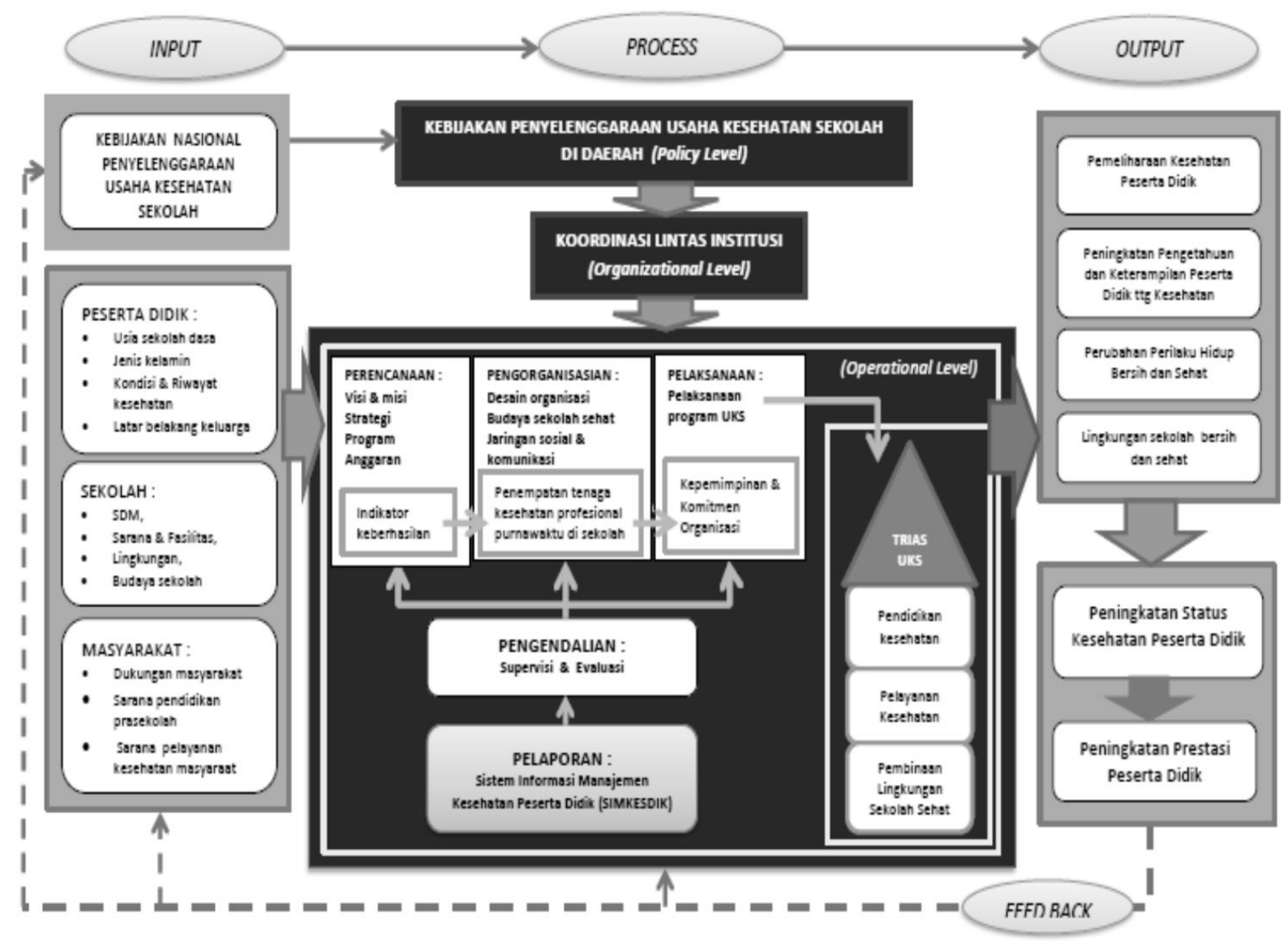

Gambar 2. Hipotetik Manajemen Kesehatan Peserta Didik di Sekolah Sumber: Oleh Peneliti Berdasarkan Hasil Penelitian

\section{MODEL HIPOTETIK PENELITIAN}

Merujuk pada kerangka pikir penelitian, hasil penelitian, telaahan teori dan konsep-konsep serta pembahasan yang telah diuraikan, maka peneliti mengajukan model hipotetik manajemen kesehatan peserta didik di Sekolah Dasar. Model hipotetik ini merupakan alternatif dari manajemen kesehatan peserta didik di Sekolah Dasar mulai dari penetapan kebijakan, penyelenggaraan secara operasional di sekolah, dan dampak penyelenggaraan terhadap peningkatan derajat kesehatan peserta didik secara holistik yang mendukung peningkatan prestasi belajar peserta didik.

Model hipotetik ini terdiri dari unsur input, process, output dan outcome. Keterangan dari 
setiap unsur dalam gambaran model hipotetik tersebut adalah sebagai berikut :

\section{Input (masukan)}

Faktor input dalam model ini terdiri dari kebijakan nasional penyelenggaraan usaha kesehatan sekolah, karakteristik peserta didik, institusi sekolah, dan masyarakat.

Kebijakan penyelenggaraan usaha kesehatan secara nasional telah ditetapkan dengan dalam Undang-Undang RI Nomor 36 Tahun 2009 tentang Kesehatan, pasal 79 dan dijabarkan secara lebih jelas dalam Peraturan Bersama empat Kementerian yaitu : Menteri Pendidikan dan Kebudayaan, Menteri Kesehatan, Menteri Agama, dan Menteri Dalam Negeri melalui Peraturan Bersama 4 Menteri Nomor 6/X/PB/2014, Nomor 7 Tahun 2014, Nomor 41 Tahun 2014, dan Nomor 81 Tahun 2014 tentang Pembinaan dan Pengembangan Usaha Kesehatan Sekolah/Madrasah. Berdasarkan kebijakan tersebut, maka seluruh sekolah mulai TK/RA, SD/MI, SMP/MTs, dan SMA/SMK/MA beserta sekolah-sekolah Luar Biasa dari semua jenjang tersebut wajib melaksanakan usaha kesehatan di sekolah sesuai dengan pedoman yang telah ditetapkan secara nasional.

Pertumbuhan dan perkembangan anak usia sekolah sangat dipengaruhi oleh faktor-faktor yang menghantarkan dirinya mencapai tahapan ini, yaitu: usia masuk sekolah (usia sekolah dasar berkisar antara 6-12 tahun), jenis kelamin, latar belakang keluarga, riwayat kesehatan sebelum fase ini, dan kondisi kesehatan saat anak masuk sekolah. Sebagian besar waktu produktif yang dimiliki anak usia sekolah, rata-rata 6-7 jam sehari dihabiskan di lingkungan sekolah. Oleh karena itu sekolah menjadi tempat yang strategis untuk anak belajar bersosialisasi dengan lingkungan sosial yang lebih luas setelah keluarga dan lingkungan sekitar rumah. Sekolah menyediakan fasilitas dan sarana pendidikan, sumber daya manusia yaitu pendidik (guru) dan staf pendidikan lainnya yang mendukung proses pembelajaran di sekolah. Sekolah mengembangkan kurikulum pembelajaran sesuai dengan kebutuhan dan kebijakan yang diberlakukan untuk memenuhi standar pendidikan secara nasional. Sekolah membangun budaya pendidikan dan lingkungan yang aman, nyaman dan kondusif untuk mempersiapkan peserta didik siap belajar dan berkontribusi dalam seluruh kegiatan pendidikan yang dilaksanakan.

Keberadaan sekolah sebagai sarana pelayanan publik mendapat perhatian dan dukungan dari masyarakat sekitar. Dukungan masyarakat terhadap keberadaan sekolah sangat terkait erat dengan kebutuhan masyarakat akan sarana pelayanan pendidikan yang memadai untuk mendidik dan mencerdaskan masyarakat. Terkait dengan aspek kesehatan, keberadaan sarana pelayanan kesehatan di masyarakat menjadi masukan yang sangat vital untuk penyelenggaraan usaha kesehatan peserta didik di sekolah. Demikian pula dengan dukungan masyarakat berupa partisipasi aktif warga masyarakat dalam mewujudkan lingkungan sekolah yang sehat dan dukungan finansial untuk meningkatkan dan mengembangkan pelayanan kesehatan di lingkungan sekolah.

\section{Process (Proses)}

Faktor yang terlibat dalam proses terdiri dari : kebijakan pemerintah dalam penyelenggaraan usaha kesehatan di sekolah termasuk kebijakan koordinasi lintas institusional untuk mendukung penyelenggaraan usaha kesehatan peserta didik di sekolah dan proses manajemen usaha kesehatan peserta didik di sekolah. Pemerintah membuat kebijakan tentang usaha kesehatan bagi peserta didik di sekolah berdasarkan pertimbangan bahwa aspek kesehatan peserta didik harus diupayakan secara optimal untuk mempersiapkan generasi penerus bangsa yang sehat, cerdas dan sejahtera. Kebijakan usaha kesehatan di sekolah dirumuskan untuk memenuhi kebutuhan peserta didik akan kesehatan holistik selama peserta didik berada di sekolah. Upaya memenuhi kebutuhan kesehatan holistik bagi peserta didik di sekolah melibatkan berbagai disiplin ilmu lintas sektor/institusi yang diorganisir oleh pemerintah sesuai dengan kebijakan pemerintah.

Sekolah sebagai unit operasional yang mengakomodasi penyelenggaraan usaha kesehatan peserta didik di sekolah perlu mengembangkan organisasi sekolah menjadi lebih fleksibel dan lebih efektif. Untuk itu diperlukan suatu konsep pengembangan organisasi (organizational development) yang mampu mengungkit semua unsur yang ada untuk mencapai tujuan yang diharapkan. Pengembangan organisasi berorientasi pada peningkatan sistem secara total, oleh karena itu fungsi penting dalam pengembangan organisasi adalah efektifitas proses manajemen yang dijalankan. Proses manajemen akan berjalan baik jika fungsi-fungsi manajemen berjalan secara sinergi. Fungsi-fungsi manajemen tersebut adalah merencanakan (planning), mengorganisasikan (organizing), menjalankan (leading), dan mengendalikan (controling).

Perencanaan dalam manajemen kesehatan peserta didik di sekolah berorientasi pada rencana 
memenuhi kebutuhan kesehatan peserta didik secara holistik di sekolah. Perencanaan pengelolaan usaha kesehatan peserta didik mengacu pada kebijakan yang ditetapkan pemerintah dalam penyelenggaraan usaha kesehatan di sekolah yang selanjutnya dijabarkan ke dalam strategi di sekolah sesuai dengan karaketristik dan kebutuhan kesehatan peserta didik secara spesifik. Perencanaan menghasilkan rumusan program yang terarah (terukur) untuk mencapai tujuan yang diharapkan. Indikator keberhasilan menjadi sangat vital keberadaannya dalam perencanaan sebagai tolok ukur dalam menilai keberhasilan program. Dengan program yang terarah pada pencapaian tujuan maka sekolah menetapkan anggaran sesuai dengan kebutuhan.

Pengorganisasian dalam manajemen kesehatan peserta didik di sekolah adalah memberdayakan semua unsur yang berkontribusi dalam penyelenggaraan usaha kesehatan peserta didik di sekolah baik dari lingkungan internal sekolah maupun dari institusi lain di luar sekolah. Sekolah mengatur pemberdayaan sumber daya manusia, sarana prasarana dan sumber daya lain yang tersedia untuk mendukung pelaksanaan usaha kesehatan peserta didik di sekolah. Dengan pemberdayaan seluruh unsur yang ada di sekolah untuk pelaksanaan usaha kesehatan peserta didik di sekolah, sekolah perlu membangun budaya organisasi yang sesuai dengan strategi tersebut sehingga pola hidup sehat di lingkungan sekolah benar-benar dapat dihayati dan dilaksanakan oleh seluruh warga sekolah. Demikian pula untuk mendukung keberhasilan usaha kesehatan bagi peserta didik di sekolah, sekolah perlu membuka peluang bagi upaya kerjasama dengan pihak-pihak yang berpotensi mengembangkan usaha kesehatan peserta didik di sekolah. Keberadaan tenaga kesehatan purnawaktu yang melaksanakan pelayanan dan promosi kesehatan di sekolah menjadi kunci keberhasilan usaha kesehatan di sekolah.

Program usaha kesehatan peserta didik di sekolah terdiri dari pendidikan kesehatan, pelayanan kesehatan, dan pembinaan lingkungan sekolah sehat yang memenuhi kebutuhan kesehatan holistik peserta didik. Keberhasilan pelaksanaan program usaha kesehatan peserta didik sangat dipengaruhi oleh kepemimpinan Kepala Sekolah dalam mengkomunikasikan, memotivasi dan menggerakkan semua unsur yang ada di sekolah untuk secara aktif melaksanakan kegiatan sesuai program yang ditetapkan dan mengambil keputusan yang tepat dalam pelaksanaan kegiatan.
Keberhasilan pelaksanaan juga dipengaruhi oleh komitmen organisasi sekolah untuk menyelaraskan kinerja, psikologikal dan kapasitas untuk belajar dan berubah dari semua unsur yang ada di lingkungan sekolah. Keselarasan kinerja terjadi ketika keseluruhan sistem organisasi sekolah yang terdiri dari struktur, sistem, orang-orang, dan budaya cocok dengan tujuan dan strategi usaha kesehatan peserta didik. Keselarasan psikologikal adalah sentuhan emosional dari semua unsur yang terlibat, khususnya Kepala Sekolah untuk mencapai tujuan, misi dan nilai-nilai yang terkandung dalam usaha kesehatan peserta didik di sekolah. Dan jika di sekolah secara terus menerus menyelaraskan kinerja dan psikologikal maka kedua hal tersebut akan mendorong kapasitas semua unsur di sekolah untuk belajar dan berubah dalam rangka meningkatkan dan mengembangkan usaha kesehatan peserta didik di sekolah.

Pengendalian dalam manajemen kesehatan peserta didik di sekolah dilaksanakan untuk memastikan dan menilai proses manajemen dilaksanakan sesuai dengan target yang telah ditetapkan. Fungsi pengendalian dalam penyelenggaraan usaha kesehatan peserta didik di sekolah meliputi kegiatan monitoring, evaluasi, pencatatan dan pelaporan. Proses pengendalian pada dasarnya terjadi di semua tahapan proses manajemen dari mulai perencanaan, pengorganisasian, pelaksanaan dan penilaian. Oleh karena itu, untuk kepentingan pengendalian perlu didukung oleh keberadaan sistem informasi manajemen kesehatan yang menyediakan sistem pengolahan data dan informasi kesehatan peserta didik secara lengkap, berkelanjutan, akurat dan real time. Sistem informasi manajemen kesehatan peserta didik akan mempermudah pencatatan, pendokumentasian dan pengolahan data kesehatan peserta didik untuk kepentingan pengambilan keputusan yang tepat untuk meningkatkan dan mengembangkan upaya kesehatan peserta didik di sekolah.

\section{Output (keluaran) dan Impact (dampak)}

Faktor output dari penyelenggaraan usaha kesehatan peserta didik di sekolah adalah pemeliharaan kesehatan peserta didik, perubahan perilaku hidup bersih dan sehat, serta perbaikan lingkungan sekolah bersih dan sehat. Sedangkan dampaknya adalah peningkatan derajat kesehatan peserta didik dan peningkatan prestasi peserta didik.

Hasil dari pengelolaan kesehatan secara holistik untuk peserta didik di sekolah adalah meningkatnya pengetahuan dan keterampilan akan 
kesehatan, terpeliharanya kesehatan peserta didik secara holistik, serta meningkatnya kesadaran peserta didik untuk berperilaku bersih dan sehat baik di lingkungan sekolah maupun di luar lingkungan sekolah. Dampak dari hasil usaha kesehatan peserta didik secara holistik tersebut diharapkan akan meningkatkan derajat kesehatan peserta didik dan akhirnya akan meningkatkan pencapaian prestasi akademik dan non akademik peserta didik sesuai dengan tujuan pendidikan di sekolah.

\section{Umpan balik (feedback)}

Hasil dan dampak usaha kesehatan peserta didik di sekolah menjadi masukan bagi upaya perbaikan, pengembangan atau perubahan kebijakan penyelenggaraan usaha kesehatan di sekolah yang ditetapkan oleh Pemerintah serta memberikan masukan untuk memperbaiki proses manajemen usaha kesehatan di sekolah.

\section{SIMPULAN DAN REKOMENDASI}

\section{Simpulan}

Hasil penelitian yang berfokus pada penyelenggaraan usaha kesehatan peserta didik sekolah dasar dengan melihat proses manajemen yang dilakukan dalam upaya mendukung pencapaian prestasi peserta didik secara optimal menunjukkan bahwa penyelenggaraan usaha kesehatan bagi peserta didik Sekolah Dasar di Kota Sukabumi dapat terlaksana sebagai akibat dari konsistensi Pemerintah Daerah terhadap implementasi kebijakan baik secara organisasional melalui koordinasi antar institusi maupun secara operasional yang dilaksanakan di sekolah-sekolah. Model hipotetik manajemen kesehatan peserta didik di sekolah dasar yang diajukan merupakan alternatif dari manajemen kesehatan peserta didik di Sekolah Dasar mulai dari penetapan kebijakan, penyelenggaraan secara operasional di sekolah, dan dampak penyelenggaraan terhadap peningkatan derajat kesehatan peserta didik secara holistik yang mendukung peningkatan prestasi belajar peserta didik. Pengajuan model hipotetik dari penelitian ini diharapkan dapat memberi masukan untuk meningkatkan kualitas pengelolaan usaha kesehatan bagi peserta didik di sekolah sehingga mampu meningkatkan derajat kesehatan peserta didik yang akhirnya berdampak pada peningkatan prestasi peserta didik di sekolah.

\section{Rekomendasi}

Berdasarkan pembahasan hasil penelitian, maka peneliti merekomendasikan model manajemen usaha kesehatan peserta didik di sekolah dasar sebagai berikut :

Pertama, Pemerintah Daerah, dalam hal ini diwakili oleh Tim Pembina UKS tingkat Kota dan Kecamatan diharapkan dapat mengakomodasi adanya pedoman manajemen usaha kesehatan bagi peserta didik di sekolah sesuai dengan keunggulan dan potensi yang dimiliki daerah saat ini untuk dijadikan acuan pelaksanaan pengelolaan di setiap sekolah yang ada di Kota Sukabumi, termasuk di dalamnya adalah pedoman yang mengatur pendanaan yang lebih jelas untuk setiap sekolah sesuai kebutuhan serta pedoman yang mengatur ketersediaan SDM profesional (petugas kesehatan profesional) yang siap melaksanakan tugas sebagai enaga kesehatan purna waktu di sekolah-sekolah.

Kedua, Tim Pembina UKS tingkat Kota dan Kecamatan diharapkan dapat mengakomodasi pengembangan sistem informasi manajemen kesehatan peserta didik sebagai perangkat yang mendukung keberhasilan proses manajemen usaha kesehatan bagi peserta didik di setiap sekolah dan mengintegrasikan penyelenggaraan usaha kesehatan peserta didik di sekolah-sekolah secara berkesinambungan.

Ketiga, Tim Pelaksana UKS di Sekolah yang dipimpin oleh Kepala Sekolah diharapkan dapat mengembangkan keterampilan manajemen usaha kesehatan di sekolah seperti model hipotetik yang diajukan, sehingga menghasilkan kinerja yang optimal dalam upaya kesehatan bagi peserta didik secara khusus, dan umumnya bagi kualitas pendidikan secara keseluruhan di sekolah. Oleh karena itu Kepala Sekolah, Guru Pembina UKS, Petugas Kesehatan Sekolah dan semua unsur yang terlibat dalam pengelolaan usaha kesehatan peserta didik di sekolah perlu mendapatkan penyegaran dan pelatihan konsep manajemen khususnya yang terkait usaha kesehatan bagi peserta didik di sekolah.

Keempat, koordinasi lintas institusi yang diprakarsai oleh Pemerintah Daerah (Tim Pembina UKS Kota dan Kecamatan) hendaknya diselaraskan dengan kebutuhan setiap sekolah dalam memenuhi kebutuhan kesehatan peserta didik secara holistik. Oleh karena itu sekolah perlu menyusun program usaha kesehatan sekolah yang memberikan peluang seluas-luasnya bagi keterlibatan berbagai pihak yang potensial untuk mendukung keberhasilan penyelenggaraan usaha kesehatan peserta didik secara holistik di sekolah. 
Kelima, penyelenggaraan usaha kesehatan peserta didik di sekolah tidak terlepas dari kebutuhan pembiayaan/pendanaan. Secara otonomi, Kepala Sekolah mengelola keuangan usaha kesehatan sekolah sesuai dengan program yang sudah ditetapkan. Oleh karena itu program usaha kesehatan sekolah perlu diperinci dengan anggaran yang jelas, sehingga setiap program dapat dipertanggungjawabkan dengan benar

\section{DAFTAR PUSTAKA}

Basch. Charles. E. (2010). Healthier Students Are Better Learners : A Missing Link In School Reforms To Close The Achievement Gap. A Research Initiative Of The Campaign For Educational Equity. The Teacher College : Colombia University. (on line). Tersedia : http://www.equitycampaign.org. Agustus 2014).

Carpenter, Bauer \& Erdogan. (2009). Principles of Management. (adapted by The Sailor Foundation). (on line). Tersedia : http://www.saylor.org/site/textbooks/Princi ples\%20of\%20Management.pdf.

November 2014)

Case \& Paxton. (2006). Children's Health and Social Mobility. Princeton University : Journal Future Of Children. Vol. 16/No.2/Fall/2006. (on line). Tersedia : https://www.princeton.edu. (18 Agustus 2014).

Cetinkaya. Senay. (2009). The Growth and Development In Healthy Child. Article. (on line).Tersedia

http://cdn.intechopen.com/pdfswm/31654.pdf. (5 Maret 2014).

Department of Defense Education Activity (DoDEA). (2007). DoDEA School Health Service Guides : Promoting Health and Wellness. Arlington -Virginia. (On Line ). Tersedia http://www.dodea.edu/StudentServices. (28 Oktober 2013).

Department of Education and Early Childhood Development - State Government Victoria. (2012). Planning for Childrea in School Age Care. Melbourne : Quality Assessment and Regulation Division Early Childhood Development Group.

Desmita. (2012). Psikologi Perkembangan Peserta Didik: Panduan bagi Orang Tua dan Guru Dalam memahami Psikologi Anak Usia SD. $S M P$, dan SMA. (Cetakan ke-empat). Bandung: PT Remaja Rosdakarya.
Foster Social Development in drldhood. Version 2. (2009). Nort Geelong : One World for Children. (on line ). Tersedia : http://www.owfc.com.au. (10 Januari 2014).

Fowler \& Dell. (2005). Stages of Faith From Infancy Through Adolescence : Reflections on Three Decades of Faith Development Theory. (on line). Tersedia : http://www.corwin.com/upm-data/6214. 10 Januari 2014).

Fowler.et al (2004). Manual for : Faith Development Research. Atlanta : Center For Research In Faith And Moral Development

Hass \& Fosse. (2008). Health and The Educational Attainment of Adolescents : Evidence From The NLSY97*. Journal of Health and Social Behaviour. 2008, Vo. 49 (June) : 178-192. (on line). Tersedia http://www.unc.edu/ ldpearce/soci820/Rea dings/presentations. (18 Agustus 2014).

Hoy \& Miskel. (2008). Educational Administration : Theory, Research, an Practice. Boston : Mc.Graw Hill.

Huitt, et al. (2009). A Systems-Based Synthesis Of Research Related To Improving Students' Academic Performance. Paper Presented at The 3rd International City Break Conference. Athens Institute For Education and Research (ATINER). (On Line). Tersedia http://www.edpsycinteractive.org/papers/im proving-school-achievement.pdf. (20 Sep 2014).

Kementerian Kesehatan RI. (2013). Puskesmas Berperanan Penting Dalam Wujudkan Sekolah Sehat. Jakarta. (On line). Tersedia : http://www.depkes.go.id. (19 September 2013).

Lear, J.G. (2007). Health at School : A Hidden Health Care System Emerges From The Shadow: The time is ripe for a viable schoolcommunity health care collaboration. (Project HOPE The people-to-People Health 
Foundation, Inc). Washington : Journal Health Affair Volume 26, number 2.

McDevitt,T \& Ormrod, J.E. (2002). Child Development and Education. New Jersey:Pearson Education. Inc.

Onis et al. (2007). Developing of a WHO Growth Referece For School-Aged Children and Adolescents. Bulletin of the World Health Organization - September 2007,85(9). Papalia, Diane.R, et al. (2008). Human Development (Psikologi Perkembangan). (terjemahan: 2010). Jakarta : Kencana Prenada Media Group.

Undang Undang RI No. 36 Tahun 2009 Tentang Kesehatan.

UNESCO. (1996). Treasure Within : Report To UNESCO of The International Commission on Education for The Twenty-first Century. France : United Nations Educational, Scientific and Cultural Organization.

(2012). Monitoring and Evaluation Guidance For School Health : Eigth indicators to support FRESH. UNESCO WHO

. (2013). Monitoring and Evaluation Guidance For School Health Programs :Thematic Indicators Supporting FRESH (Focusing Resources and Effective School Health). UNESCO : WHO_U.S Department of Health and Human Services \& U.S Department of Education (2010). Joint Guidance on the FERPA and HIPAA To Student Health Record. http://www.hhs.gov/ocr/privacy/hipaa/unde rstanding/coveredentities/hipaaferpajointgui de. (26 Agustus 2014).

Valois, R.F. Slade \& Ashford. (2011). The Healthy School Communities Model : Aligning Health and Education in The School Setting. New York : ASCD. (on line). Tersedia : http://www.ascd.org/ASCD/pdf/siteASCD/ publications/Aligning-Health-

Education.pdf. (18 Agustus 2014).

Wahab, A. A. (2011). Anatomi Organisasi dan Kepemimpinan Pendidikan : Telaah Terhadap Organisasi dan Pengelolaan Organisasi Pendidikan. Bandung : Alfabeta. 